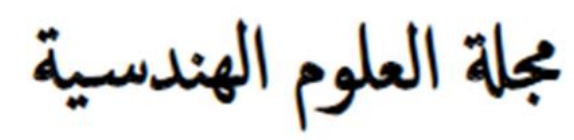

FES Journal of Engineering Sciences

http://journal.oiu.edu.sd/ojs/index.php/fjes/index

\title{
The Effect of Discharge Rejected Brine into the Surface Water on the coast of Port Sudan city
}

\author{
Mustafa SirElkhatim Mustafa ${ }^{1}$ and Zubeir Aleid Hamad ${ }^{2}$ \\ 1 Chemical Engineering Department, Red Sea University, Port Sudan, Sudan. \\ 2 Mowah Company, Saudi Arabia \\ * Corresponding author: Mustafa SirElkhatim (abulogain2007@gmail.com). \\ Article history: Received 05 March 2019, Received in revised form 23 May 2020, Accepted 29 September 2020
}

\begin{abstract}
The general aim of this study is to focus on the effects of discharge reject brine into the surface water in Port Sudan city. It considers baseline study in Port Sudan. Three samples of water were taken from sea land lagoon by using TCD (Temperature, Conductivity and Depth) device, and sample from open sea (Abu Hashish). All samples were collected during summer and winter seasons. The results showed a significant increase in salinity $39.13-49.86,39.91-47.45,38.62$ - $38.87,38.48$ 39.27 psu respectively, of the surface water when mixed with the discharge reject brine, this will absolutely affect the marine life. Also the continuous discharge of rejected brine into water near the intake desalination plants will affect the characteristics of the feed water.
\end{abstract}

Keywords: Rejected brine, Port Sudan City, Desalination plant, Surface Water.

\section{INTRODUCTION}

Port Sudan city suffers from scarcity and quality in drinking water, where the daily consumption of drinking water was estimated at 120000-150000 $\mathrm{m}^{3} /$ day. Water available from various sources (Khor Arbaat and groundwater) ranges from 60000-30000 m3/day with a water deficit of about $66 \%$. In general, the overall situation of the city is characterized by regular shortages. The shortage of water is compensated by desalination plants [1]. It was estimated that the world production of desalination water exceeds 30 million cubic meters per day. There are many options for brine management includes: discharge to surface water or wastewater treatment plants; deep well injection; land disposal; evaporation ponds; and mechanical / thermal evaporation [2]. The rejected brine of high salt concentration was drained into the sea causing environmental impact of aquatic life in the red sea [3].

During the last few decades existing freshwater sources have become increasingly limited in many regions of the world [4,5], particularly in countries along the Arabian Gulf, the Mediterranean coast and the Red Sea, due to the elevated consumption and low precipitation occurring in these zones [6,7]. Desalination was a maturing technology that has been widely utilized for freshwater supply throughout the world for many years [5,8].Therefore, seawater desalination has been considered as a feasible alternative available to satisfy the demand of water, and the number of projected and constructed desalination plants has increased throughout this region in recent years[7].Although there are several desalination technologies, such as those based on thermal processes(e.g. multi-stage flash, multi-effect distillation and vapour compression)or the ones based on membrane processes (e.g. electrodialysis, reverse osmosis, nanofiltration),currently the reverse osmosis (RO) method is the preferred desalination technique in these new facilities, mainly due to its low energy and space consumption and the reduction in the cost of the potable water obtained [5,9-11]. RO consists of applying external pressure to a concentrated solution, like seawater, in order to force the flow of water molecules through a semi-permeable membrane, producing a permeate which consists of fresh water and rejected brine [12]. Therefore, this brine is fundamentally water, relatively concentrated in dissolved salts (44-90 psu (Practical Salinity Unit)) by a factor related to the water recovery 
rate (product water/ feed water, .30-70\%) utilized during the desalination process [13]. Additionally, some chemicals (such as biocides, anti-scalants, coagulants, antifoaming agents, etc.) used in the desalination processes, and toxic metals (if the discharge water has been in contact with metallic materials) may accompany the brine $[9,10,14,15]$.

There are different options for the concentrate disposal from a desalination plant such as its discharge into the sea, into deep wells or into evaporation ponds, its treatment on wastewater plants or the production of salt and other minerals [16-20]. But cost plays an important role in the selection of the disposal method and today ocean brine disposal was considered the least expensive one $[10,15,18,19]$. If the concentrate is discharged directly into the sea, it will form a plume of elevated density that will descend to the sea floor and extend horizontally following the slope of the sea bottom bathymetry [21]. This hypersaline mass of water could negatively affect several benthic marine organisms around the discharge point that usually live in stable salinity environments $[11,15,22,23]$. The most sensitive communities will be the most affected, perhaps resulting in total disappearance of these species inside the area of brine influence. To date, available information regarding the behavior of these hypersaline effluents and their effect on the marine ecosystem is insufficient [21,24,25]. However, the discharge of brine into the sea requires particular attention and scientific assessment of possible impact on the marine environment. The magnitude of these potential impact will depend not only on the characteristics of the desalination plant and its rejected brine, but also on the nature of the physical (i.e., bathymetry, hydrodynamics, etc.) and biological conditions of the receiving marine environment $[10,15,18,23]$. The main objective of this paper was to estimate the area of influence affected by brine effluent of reverse osmosis (SWRO) desalination plants in Port Sudan city.

Beside that the study illustrated how the behavior of these brine discharges can differ widely according to discharge characteristics. This information may be useful to predict effluent distribution in order to minimize the harmful effects of brine discharges into the sea.

\section{MATERIAL AND METHODS}

2.1. Location and description of the studied desalination plants and their brine discharge:

We carried out the monitoring of the brine discharge from two SWRO desalination plants with different characteristics, located in the lagoon (sea land) and open sea (Abu Hashish), over a period of several seasons (Figs. 1 and 2). The monitoring programs have been adapted to these characteristics and to the local conditions existing in the brine disposal areas.

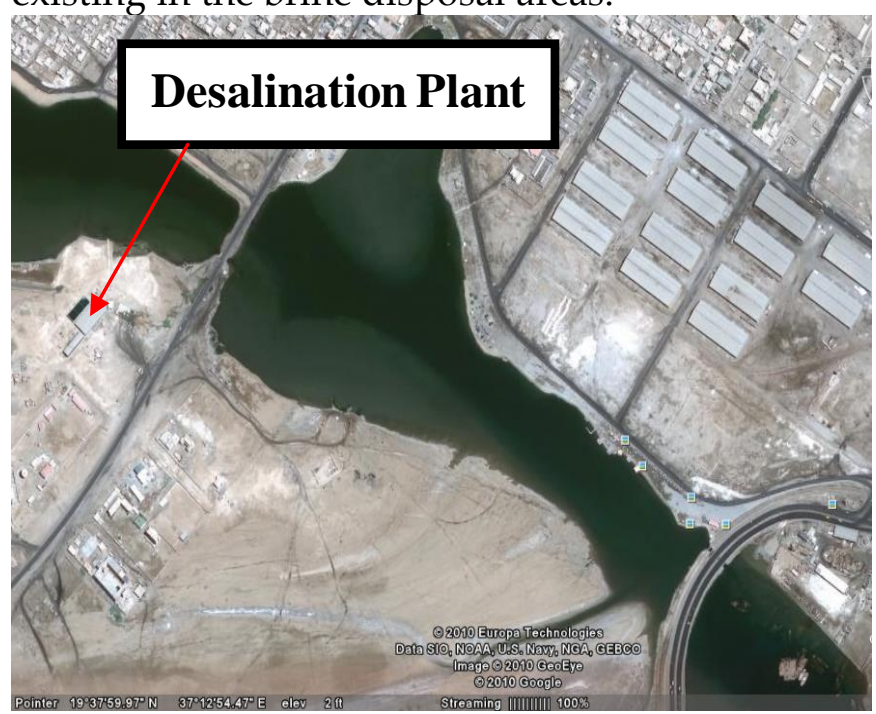

Fig.1. Desalination Plant - Sea Land lagoon

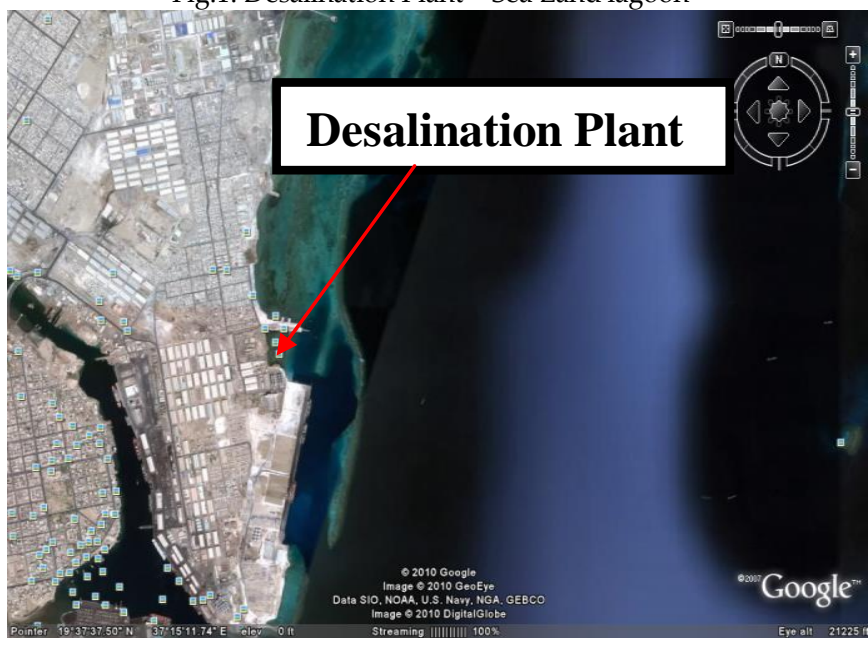

Fig.2. Location of samples collection in open sea (Abu Hashish)

\subsection{Samples Collection}

60 samples of water were taken from sea land lagoon at different stations from in summer (May, June) and winter (April, September) seasons. All samples taken by using conductivity, temperature and depth(CTD) devices with a measuring range of $0-70$ psu and a resolution \pm 0.01 psu. , as shown in Fig.(3). On the other hand,20 samples from open sea (Abu Hashish) were also taken at different stations 
from in summer (May, June) and winter (April, September).

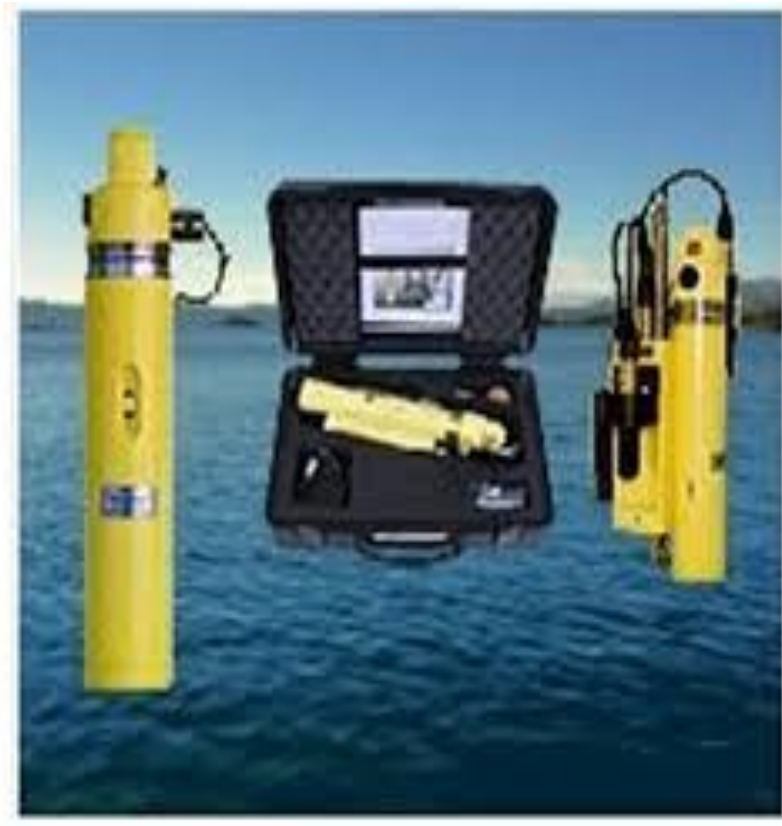

Fig.3. TCD device

\section{RESULTS AND DISCUSSION}

The results in Figs. 4-7 illustrated that observed increase of salinity between $39.13-49.86$, 39.91$47.45,38.62-38.87,38.48-39.27$, respectively. The range of salinity of the coastal of port Sudan between 37- 38 ppt in summer and winter respectively [26]. In this paper we have presented the results of the monitoring of the brine effluent originating from several SWRO desalination plants, and we discuss this results with the range of salinity at port Sudan costal, we found the effect of discharge of reject brine desalination plants by increasing the salinity above $38 \mathrm{ppt}$ [26]. This hypersaline mass of water could negatively affect several marine organisms around the discharge point that usually live in stable salinity environments $[11,15,22,23]$. The most sensitive communities will be the most affected, perhaps resulting in total disappearance of these species inside the area of brine influence [27].

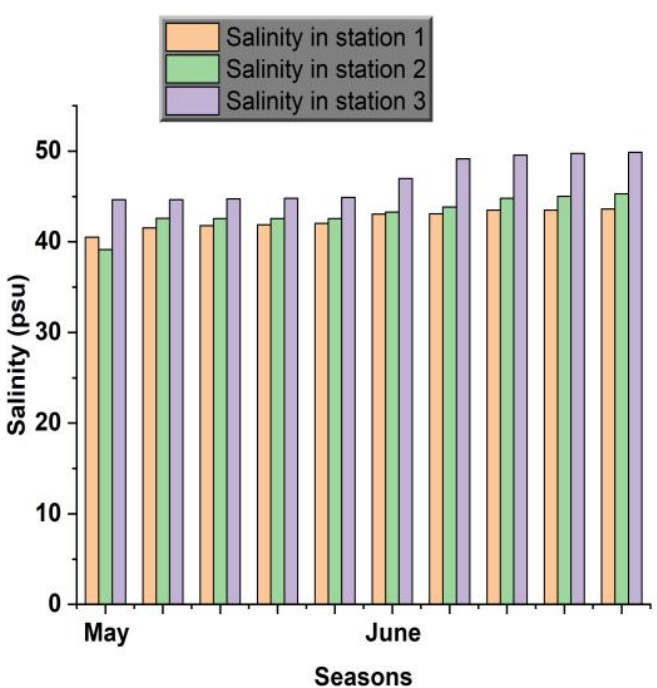

Fig.4. Comparison between increase salinity in summer

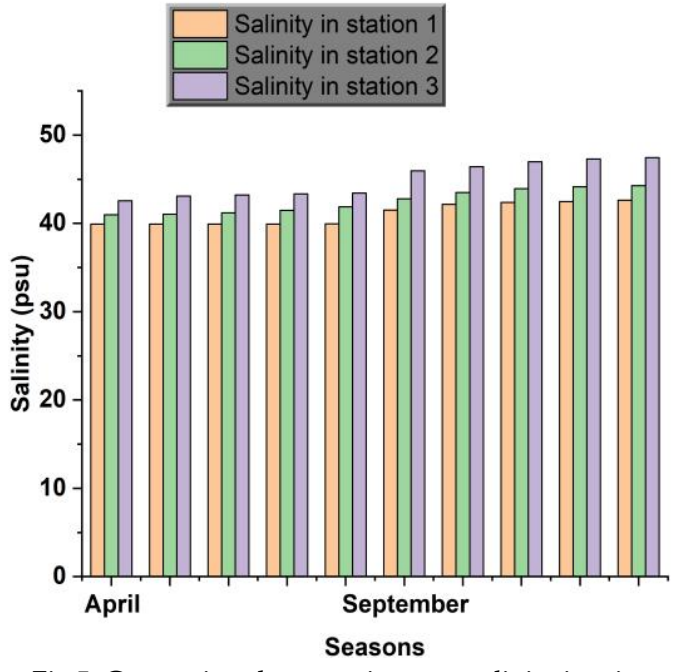

Fig.5. Comparison between increase salinity in winter

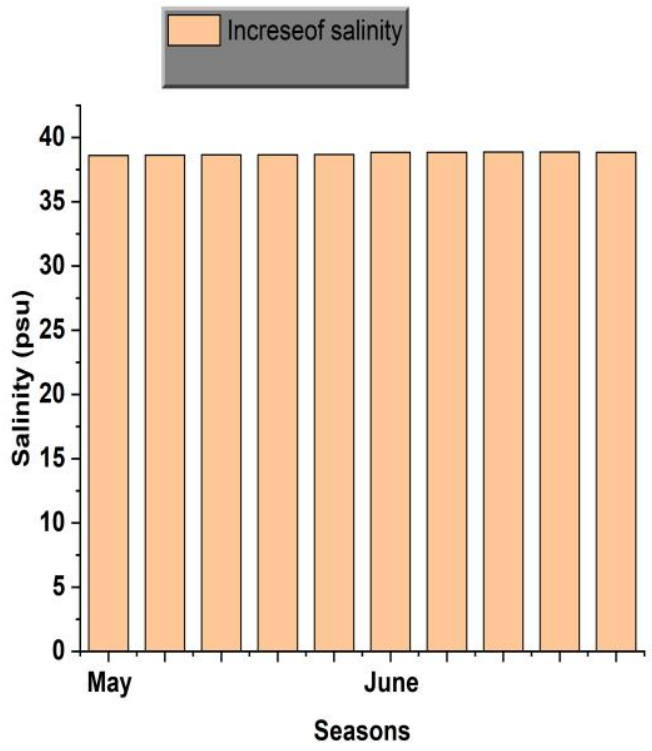

Fig.6. Comparison between increase salinity in summer 


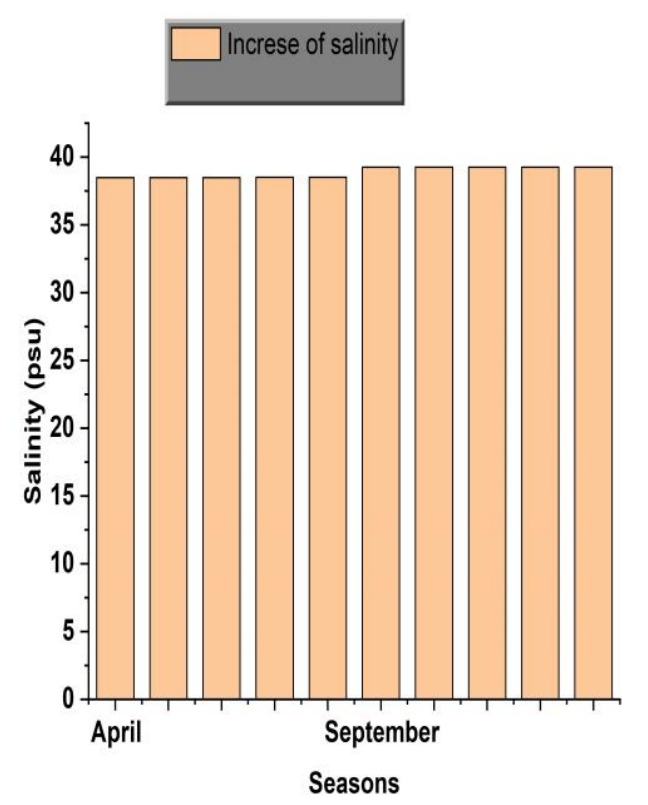

Fig.7. Comparison between increase salinity in winter

\section{CONCLUSION}

The paper focuses on the effect of discharge reject brine directly in surface sea water. The results showed that there was an increase in coastal water salinity of Port Sudan, which will negatively affect marine organisms. The study recommended that:

\section{1- Use rejected brine to produce salt.}

2- Use nozzles to desperation reject brine of widely area.

3- Construction of desalination plants on open sea.

\section{REFERENCES}

[1] Port Sudan Water and Sanitation Rehabilitation and Expansion Assessment and Programme Design February 2015 - Mott MacDonald. [2] Muftah H. El-Naas (2011). Reject Brine Management, Desalination, Trends and Technologies, Michael Schorr (Ed.), ISBN: 978-953-307-311-8, In Tech, Available from:

http://www.intechopen.com/books/desalinationtrendsand-technologies/reject-brine management

[3] M. S. E. Mustafa, G.A.Gasmelseed . Desalination plants in the red sea state. (IJESIT) Volume 4, Issue 1, January 2015

[4] P.H. Gleick, Water in crisis: paths to sustainable water use, Ecol. Appl., 8 (1998) 571-579.

[5] M. Schiffler, Perspectives and challenges for desalination in the 21st century, Desalination, 165 (2004) 1-9

[6] J.A. Medina San Juan, La desalación en España. Situación actualy previsiones. Conferencia Internacional: El Plan Hidrológico Nacional y la Gestión Sostenible del Agua. Aspectos medioambientales, reutilización y desalación, Zaragoza, 2001.

[7] S. Lattermann and T. Höpner, Environmental impact and impact assessment of seawater desalination, Desalination, 220 (2008) 1-15. [8] G.L. Meerganz von Medeazza, Direct and socially-induced environmental impacts of desalination, Desalination, 185 (2005) 57-70. [9] A.J. Morton, I.K. Callister and N.M. Wade, Environmental impacts of seawater distillation and reverse osmosis processes, Desalination, 108 (1996) 1-10.
[10] R. Einav, K. Harussi and D. Perry, The footprint of the desalination processes on the environment, Desalination, 152 (2002) 141-154. [11] A. Purnama, H.H. Al-Barwani and M. Al-Lawatia, Modeling dispersion of brine waste discharges from a coastal desalination plant, Desalination, 155 (2003) 41-47

[12] C. Fritzmann, J. Löwenberg, T. Wintgens and T. Melin, State-ofthe-art of reverse osmosis desalination, Desalination, 216 (2007) 1-76.

[13] M. Fariñas Iglesias, Ósmosis Inversa. Fundamentos, tecnologíay aplicaciones, McGraw Hill/Interamericana de España, Aravaca, 1999. [14] T. Höpner and J. Windelberg, Elements of environmental impact studies on coastal desalination plants, Desalination, 108 (1996) 11-18. [15] S. Lattemann and T. Höpner, Seawater desalination. Impacts of brine and chemical discharges on the marine environment, Desalination Publications, L'Aquila, 2003.

[16] P. Glueckstern and M. Priel, Optimized brackish water desalination plants with minimum impact on the environment, Desalination, 108 (1996) 19-26.

[17] D. Squire, J. Murrer, P. Holden and C. Fitzpatrick, Disposal of reverse osmosis membrane concentrate, Desalination, 108 (1996) 143-147.

[18] M. Ahmed, W.H. Shayya, D. Hoey, A. Mahendran, R. Morris and J. Al-Handaly, Use of evaporation ponds for brine disposal in desalination plants, Desalination, 130 (2000) 155-168.

[19] M. Ahmed, W.H. Shayya, D. Hoey and J. Al-Handaly, Brine disposal from reverse osmosis desalination plants in Oman and the United Arab Emirates, Desalination, 133 (2001) 135-147.

[20] M. Ahmed, A. Arakel, D. Hoey, M.R. Thumarukudy, M.F.A. Goosen, M. Al-Haddabi and A. Al-Belushi, Feasibility of salt production from inland $\mathrm{RO}$ desalination plant reject brine: a case study. Desalination, 158 (2003) 109-117.

[21] Y. Fernández-Torquemada, J.M. González-Correa and J.L. Sánchez-Lizaso, Preliminary results of the monitoring of the brine discharge produced by the SWRO desalination plant of Alicante (SE Spain). Desalination, 182 (2005) 395-402

[22] J.V. Del Bene, G. Jirka and J. Largier, Ocean brine disposal, Desalination, 97 (1994) 365-372.

[23] R. Einav and F. Lokiec, Environmental aspects of a desalination plant in Ashkelon, Desalination, 156 (2003) 79-85.

[24] J.L. Pérez Talavera and J.J. Quesada Ruiz, Identification of the mixing processes in brine discharges carried out in Barranco del Toro Beach, south of Gran Canaria (Canary Islands), Desalination, 139 (2001) 277-286.

[25] N. Raventos, E. Macpherson and A. García-Rubiés, Effect of brine discharge from a desalination plant on macrobenthic communities in the NW Mediterranean, Mar. Environ. Res., 62 (2006) 1-14.

[26] Por, F. D. (2012-12-06). The Legacy of Tethys: An Aquatic Biogeography of the Levant. Springer Science \& Business Media. ISBN 9789400909373.

[27] Yolanda Fernández-Torquemada, José Miguel Gónzalez-Correa, Angel Loya, Luis Miguel Ferrero, Marta Díaz-Valdés \& José Luis Sánchez-Lizaso (2009): Dispersion of brine discharge from seawater reverse osmosis desalination plants, Desalination and Water Treatment, 5:1-3, 137-145. 